\title{
The Impact of Principals' Transformational Leadership Practices on Tutors' Self-Efficacy Beliefs in the University Colleges of Education in Ghana
}

\author{
By Robert Afayori (BA, PGDE, MPHIL, Ed.D, PhD)
}

\begin{abstract}
Research studies have consistently demonstrated the statistically significant relationships between principals' transformational leadership practices and teachers' sense of efficacy in student engagement, instructional strategies and classroom management. What is less studied and very much less researched is the extent to which principals' transformational leadership practices account for the variances in teachers' sense of efficacies in tertiary institutions. This current study investigates tutors' perceptions of the specific principals' transformational leadership practices which impact on their sense of efficacy in student engagement, instructional strategies and classroom management in the university colleges of education in Ghana. Data was garnered using the PLQ and TSES questionnaire instruments. Following cluster sampling procedures, 629 tutors from 15 university colleges were selected for the study. Descriptive statistics, correlational and multiple regression analyses were to index the specific principals' transformational leadership practices which accounted for the total variances in the three dimensions of tutors' sense of efficacy. Findings indicate that principals' transformational leadership practices such as providing vision and direction and holding high performance expectations accounted for most of the variances in tutors' sense of efficacy in all three factors. This implies that principals who frequently exercise these leadership qualities are more likely to enhance their tutors' self-efficacy beliefs in student engagement, instructional strategies and classroom management.
\end{abstract}

Keywords: Principal Leadership Practices, transformational leadership, teacher performance, teacher self-efficacy beliefs, tutor sense of efficacy.

DOI: $10.7176 / \mathrm{JEP} / 11-3-04$

Publication date: January $31^{\text {st }} 2020$

\section{Introduction}

Remarkable attempts have been made by governments and institutions of learning to raise the standards of education for all students through educational research and reforms (Day et al., 2016). While most of these research studies have contributed to informing educational policy development and implementation, most of these policies emphasise on the need to maximise student achievements with limited available resources. Most of the research studies that focus on school improvements and effectiveness principals' leadership practices as a significant factor (Marks and Printy, 2003; Hallinger and Heck, 2010; Shatzer et al., 2014; Day et al., 2016). For instance, Day and colleagues (2016) report that principal leadership practices have the potential to influence positively or negatively various elements of the school such as the organisation of the school, its culture, teacher and staff attitude, student learning and academic achievements (p.222-223).

Within the context of efforts in school improvement and effectiveness, the role of teachers as 'leaders of teaching and learning in the classroom' is vital (Rhodes and Brundrett, 2010:156). To be effective leaders of teaching and learning, Rhodes and Brundrett (2010) emphasise that 'teachers need to know how to lead lessons, inspire learners, have high expectations, enable good learning experiences through planning... probe knowledge and understanding, monitor performance and give feedbacks' (p.156). For teachers to achieve such significant levels of performance, they need the support and guidance of good and effective principal leadership. This study therefore investigates the impact of principals' leadership on teacher efficacy beliefs. Empirical studies in the area consistently demonstrate that teacher efficacy is a significant predictor of their performance (Hipp, 1996; Goddard et al., 2004; Ross and Bruce, 2007; Gavora, 2010; Versland and Erickson, 2017). What is less studied and much less researched is the impact of principal transformational leadership practices on tutors' sense of efficacy in the colleges of education in Ghana.

Research studies show that school principals are strategically placed to influence various elements of the school including school climate and teacher effect variables such as teacher sense of efficacy (Hipp, 1996; Bredeson and Johannsen, 2000; Espinoza, 2013; Gkolia et al., 2018). Tutor self-efficacy beliefs represents tutors' belief in their ability to plan instructional materials and achieve instructional goals. Since the role of college principals also involves positively influencing tutor behaviour to enhance their teaching performance, this study examines tutors' perceptions of how their principal transformational leadership behaviours impact on their selfefficacy beliefs in student engagement, instructional strategies and classroom management. In the many studies that have been conducted in this area, there is hardly a study which examines the relationship between these two key variables in tertiary institutions. As the literature review shows, the scarcity of literature in this area gives 
warrant to this current study

\section{Literature Review}

\subsection{Principals' Transformational Leadership Practices}

There are many leadership models in education which define and shape the sort of practices principals often exercise in their leadership oo schools. Some of these leadership models include managerial, transactional, instructional, transformational, distributed, moral, participative, emotional, contingent, and postmodern leadership (see, Bush, 2011: 36). While many research studies in education have explored the effects of these leadership styles on schools (see, Hallinger, 2003; Hallinger and Heck, 2012; Shatzer et al., 2014; Day et al., 2016), they identify 'instructional leadership' and 'transformational leadership' as the most effective leadership models for school improvements and effectiveness. Whereas transformational leadership is said to directly impact on school conditions and teacher performance, instructional leadership impacts directly on student learning Hallinger, 2003; Shatzer et al., 2014). In this way, if transformational leadership is known to produce direct influence on school conditions and on teacher performance, then what essentially constitutes this leadership model?

Literature on transformational leadership indicates that this form of leadership is based on the assumption that when the central focus of leadership is directed to the commitment and capacities of organisational members, it produces in the members, higher levels of personal commitment to organisational goals and greater capacity and motivation to accomplishing these goals (Leithwood et al., 1999; Leithwood and Sun, 2012). Thus, transformational leadership is built on the conception that given the requisite support, members of an organisation 'become highly engaged and motivated by goals that are inspirational because those goals are associated with values which they strongly believe' (Leithwood and Sun, 2012: 388). So, what transformational leaders need to do is identify these goals and direct the kind of leadership practices that positively influence followers to work towards the realisation of the defined goals of the organisation (Leithwood and Sun, 2012: 389). In this way, the central focus of transformational leadership is the development of members and the improvement of working conditions as an effective means to accomplishing organisational goals.

The concept was first developed by James McGregor Burns in 1978 to describe the ideal relations between leaders and followers in an organisation. He described it as the leader's ability to appeal to or persuade followers to act in response to certain goals that represent the values, needs and motivations of both leader and followers. For Burns (1978), transformational leadership is not so much the exercise of one's authority over others but the leader's ability to appeal to the shared values of followers in response to organisational goals. Bass (1985) however extended Burns' (1978) concept to embrace a two-factor theory of leadership where transformational and transactional leadership are viewed as two ends of a leadership continuum. According to Bass (1985), while transactional leadership practices involve an exchange process (e.g. salary recognition or offering contingent rewards for good performance) and are good for maintaining the standards of performance in the organisation in the short-term, transformational leadership practices appeal to the long-term shared goals and interests of both followers and leaders in the organisation (Bass and Bass, 1985; Avolio, 1994). In this way, Bass (1985) identified the following factors as characteristic of leaders who exercise transformational leadership practices: idealised influence, inspirational motivation, intellectual stimulation and individualised consideration, contingent reward, management-by-exception and laissez-faire leadership. Bass and Avolio used their Multifactor Leadership Questionnaire (MLQ Form 5X) to measure these leadership practices.

Transformational leadership however 'found a receptive audience in education in the 1990s due to the reaction against the top-down policy driven approach to school leadership that predominated the late 1970s and early 1980s' (Leithwood, 1994: 500; Hallinger, 2003: 335). Leithwood and colleagues (1992; 1994; 1999) introduced the concept into education in response to the needs of the school restructuring initiatives in the 1990s. They extended Burns' (1978) and Bass' (1985) model to include other leadership characteristics such as: building school vision, establishing school goals; providing intellectual stimulation; offering individualized support; modelling best practices and important organizational values; demonstrating high performance expectations; creating a productive school culture; and developing structures to foster participation in school decision-making (Leithwood, 1994; Leithwood et al., 1999; Leithwood and Sun, 2012: 399-401).

Day and colleagues (2016) also indicate that principals who exercise forms of transformational leaders exercise practices engage in actions such as: providing vision and inspiration, setting directions, developing teachers, (re)designing the conditions of the school, and establishing structures that enhance the quality of teaching and learning (p.224). Leithwood and colleagues (1994; 1996) developed two instruments for measuring the aforementioned principals' transformational leadership Nature of School Leadership Survey (NSLS) and Principal Leadership Questionnaire (PLQ). While some research studies identify weaknesses in the transformational leadership model (see, Yukl, 1999; Allix, 2000; Hartley, 2004; Bush, 2011: 86), other research studies consistently demonstrate the significant relationships between transformational leadership practices and positive teacher attitude, teacher commitment to school goals, teacher job satisfaction and teacher performance efficacy (Leithwood, 1994; Hallinger, 2003; Hallinger and Heck, 2010; Urick and Bowers, 2013; Shatzer et al., 
2014; Day et al., 2016). If transformational leadership practices influence teacher-effect-variables in this way, to what extent does it account for variances in tutors' sense of efficacy in the university colleges of education in Ghana?

\subsection{Techers' Sense of Efficacy}

Teachers' sense of efficacy is derived from Bandura's (1997) social cognitive theory of 'perceived self-efficacy' which he presented as a self-regulatory mechanism which determines human performance. Bandura (1997) defined 'perceived self-efficacy as 'beliefs in one's capabilities to organise and execute the courses of action required to produce given attainments' (3). For Bandura (1997), perceived self-efficacy is a performance predictor because it influences 'the courses of action people choose to pursue, how much effort they put forth in given endeavours, how long they will persevere in the face of obstacles and failures, their resilience to adversity... and the level of accomplishment they realised' (p.2). In this way, a teacher's sense of efficacy refers to the teacher's beliefs in his or her ability to plan classroom instructions and accomplish instructional objectives (Gavora, 2010). TschannenMoran and colleagues (1998) defines it as the 'teacher's belief in his or her capacity to organise and execute courses of action required to successfully accomplish a specific teaching task in a particular context' (p.233). For Ross and Gray (2006), it is 'a teacher's expectation that he or she will be able to bring about student leaning' (p.182).

According to Bandura (1997), 'social cognitive theory posits multifaceted causal structures that address both the development of competence and the regulation of action' (p.34). While competence is developed through the knowledge and skills one acquires, these competencies guide and determine the appropriateness of the actions required to achieve given outcomes within particular circumstances (Bandura, 1997). Bandura (1997) assigned this development of knowledge and skills to personal capabilities (p.34). However, the regulation of action is determined by perceived self-efficacy. This is because perceived self-efficacy determines the degree to which the knowledge and skills acquired (personal capabilities) leads to expected or desired outcome. It influences the course of action people choose to pursue, how much effort they put forth in given endeavours, how long they will persevere in the face of obstacles and failures, their resilience to adversity... and the level of accomplishment they realised' (Bandura, 1997: 2).

Perceived self-efficacy possesses such self-regulatory influence because it influences the person's cognitive, motivational, affective and selection (decision-making) processes. As Bandura put it, self-efficacy beliefs determine whether people think productively, pessimistically, or optimistically (cognitive processes). They affect how well they motivate themselves and persevere in the face of difficulties (motivations). These beliefs influence the quality of the emotional well-being people achieve and their vulnerability to stress and depression (affective states). They affect the life choices they make which sets the course of their life paths (decision-making) (see, Bandura, 1997:116-161; Bandura, 2008; cited in Versland and Erickson, 2017:3). In other words, self-efficacy beliefs are robust predictors of personal performance.

Perceived self-efficacy is different from 'self-esteem' because while perceived self-efficacy is concerned with judgements of personal capabilities, self-esteem is concerned with judgements of self-worth. However, self-worth is a judgement of how much one likes or dislikes oneself which is entirely different from the judgement of one's capabilities. For Bandura (1997), there is no fixed relationship between the two, in that, people can judge themselves to be inefficacious in a given activity without suffering the loss of their self-esteem because they do not relate the task to their self-worth. In the same way, a person may regard himself or herself as highly skilled in a given activity but takes no pride in performing it well (Bandura, 1997:11). So, the judgements of self-esteem and perceived self-efficacy represent judgements of different phenomena in which self-liking does not necessarily begets performance attainments (Bandura, 1997:12).

Goddard and colleagues (2004) indicates within the context of a teacher's self-efficacy, perceived selfefficacy can be referred to variously as teacher sense of efficacy, teacher efficacy beliefs, teacher efficacy judgements, or teacher perceived efficacy (p.4). Where these terms are used interchangeably in this study, they convey the same meaning. As a self-efficacy belief construct, teacher self-efficacy beliefs influence the teacher's thoughts, motivations, emotions and decision-making processes. It therefore contributes to inhibiting or enabling their performance. As Ross and Bruce (2007) intimated, teachers with high sense of efficacy always believe that they will be successful. So, they set for themselves higher goals, try harder to achieve these goals, and persist through obstacles and difficulties. However, teachers with lower sense of efficacy have little belief in their successes. They avoid expending efforts since failure is inevitable, and repeated failure threatens self-esteem (p.50).

Bandura's (1997) identified four sources for the development of self-efficacy beliefs: mastery experience, vicarious experience, verbal persuasion and affective state. These four sources equally influence teachers' efficacy beliefs in the same way. Considered briefly, mastery experience concerns a teacher's demonstration of his or her successes in performing a teaching task, thereby building his or her competencies in undertaking the same teaching task. Vicarious experiences underline the teacher's attainment of a high sense of efficacy through observation and modelling of successful teachers. Mentoring is vital here. Verbal persuasion however concerns the emotional 
support, encouragement, coaching and feedbacks that teachers receive from their colleagues and superiors which augment their self-beliefs beliefs. Physiological or emotional state points to how teachers' excitement and enthusiasm about a teaching task provides cues about anticipated teaching success, while their stress, anxiety and depression lead to negative judgements about their efficacy beliefs (Gavora, 2010:3).

Since the development of the construct, various instruments such as the RAND Studies (1978), the Dembo and Gibson Scale (1984), Badura's (1997) scale, most of these instruments focused on measuring two aspects of teachers' sense of efficacy: personal teaching efficacy (PTE) and general teaching efficacy (GTE). Their reliabilities and validities have equally been questioned (see Tschannen-Moran and Hoy, 1998). However, the only viable instrument for measuring teacher efficacy is the teacher sense of efficacy scale (TSES) developed by Tschannen-Moran and Hoy (2001). Klassen and colleagues (2011: 40) described it as the best so far, for measuring teacher self-efficacy and collective efficacy beliefs. The instrument measures three areas of teachers' sense of efficacy: student engagement, instructional practices, and classroom management (see, Tschannen-Moran and Woolfolk Hoy, 2001: 783-805). While efficacy in student engagement focuses on teachers' beliefs in their ability to create the conditions that ensure effective teaching and motivate student learning, efficacy in instructional strategies concerns teachers' beliefs in their ability to organise the instructional programme to achieve instructional outcomes. However, efficacy in classroom management relates to teachers' beliefs in their ability to handle problems and disruptive behaviours in the classroom to ensure effective teaching and learning.

Over the past two decades, many research studies have explored the impact of this efficacy construct on teacher performance, job satisfaction, commitment and student achievements (Goddard et al., 2004; Ross and Gray, 2006; Ross and Bruce, 2007; Klassen et al., 2011; Versland et al., 2017). For instance, in their systematic review of empirical research studies on teacher self-efficacy beliefs between 1998-2009, while Klassen and colleagues (2011) acknowledged the scholarly consensus that teacher efficacy is a significant predictor of teacher performance, most of the reviewed studies examined the impact of the concept in multifaceted directions. While some research studies focus on exploring further the sources for the development of teacher self-efficacy beliefs (TschannenMoran et al., 1998; Henson, 2002; Goddard et al., 2004Tschannen-Moran and McMaster, 2009), others focused particular attention on the methodological approaches and measurements used for investigating the concept (Gibson and Dembo, 1984; Henson, 2002; Wheatley, 2005). Yet, other studies explored its effects on teacher performance, job satisfaction and professional commitment (Goddard and colleagues, 2004; Capara et al., 2006; Ware and Kitsantas, 2007; Demirdag, 2015).

Klassen and colleagues (2011) also found studies which examined the relationship between principals' transformational leadership and teacher self-efficacy beliefs in schools (Ryan, 2007; Walker and Slear, 2011; Espinoza, 2013; Shumate, 2013; Ling et al., 2015; Short, 2016; Versland and Erickson, 2017). Having reviewed most of the above literature in the area, it is observed that few studies have examined the extent to which teachers or tutors' perceptions of their principals' transformational leadership practices impact on their self-efficacy beliefs. This current study investigates the relationship between these two key variables and identifies the specific leadership practices which directly impact the most on tutors' sense of efficacy in the colleges of education in Ghana.

\subsection{Leadership Factors Accounting for Variations in Teachers' sense of efficacy}

This section explores literature on 'the extent to which principals' transformational leadership practices impact on teachers' sense of efficacy in student engagement, instructional strategies and in classroom management. The purpose is to identify the number of research studies in the area and to define the research gap which this current study explores.

\subsubsection{Teachers' Sense of Efficacy in Student Engagement}

A teacher's sense of efficacy in student engagement concerns the extent to which a teacher is able to creatively relate to students in ways that inspire and motivate them to set up and achieve higher learning goals for themselves. Studies show that that positive teacher-student engagement creates suitable conditions for teachers to teach and motivates students to learn and develop higher levels of self-efficacy beliefs (Tschannen-Moran and Woolfolk Hoy, 2001:797; Tucker et al., 2002; Linnenbrink and Pintrich, 2010). For instance, Ross and Bruce (2007) report that teachers with higher self-efficacy beliefs are more successful because they attend to the needs of both higher and lower ability students. Such teachers have positive attitudes and build friendly relationships with students which motivate them to learn better (Ross and Bruce, 2007: 51).

While teachers' sense of efficacy in student engagement is a vital factor in teacher performance efficacy, there are very few studies which investigate the impact of principals' transformational leadership practices on this efficacy variable. For instance, Ryan (2007) conducted a study on principals' transformational leadership effects on teachers' sense of efficacy in elementary, middle and high schools in Texas, (U.S.A). Data was garnered from 168 teachers to analyse the relationship between the two key variables. While the results of the analyses indicated that teacher efficacy in student engagement recorded the strongest relationship with all areas of principals' transformational leadership behaviours (Ryan, 2007: 84), the study did not examine the extent to which principals' 
leadership impacted on teachers' sense of efficacy. Other research studies also examined the relationships between the two key variables without ascertaining the degree of impact of the independent variable on the dependent (see, Shumate, 2011; Simmons, 2013; Short, 2016).

However, in the studies conducted by Espinoza (2013) involving 283 teachers in elementary and secondary schools in South Texas (USA), the study used the TSES and PLQ to gather data on the extent to which teachers' perceptions of their principals' transformational leadership impacted on their sense of efficacy. Exploratory factor analysis (EFA) and confirmatory factor analysis (CFA) were to extract two factors of teachers' sense of efficacy and two factors of principals' transformational leadership. Thus, teachers' sense of efficacy in student engagement was deselected. However, efficacy in instructional strategies and classroom management were analysed together with transformational leadership practices such as setting directions and redesigning the organisation.

Mehdinezhad and Mansouri (2016) also conducted a study in the area using a sample size of 254 elementary, middle and secondary school teachers in Iran. The study used the Multifactor Leadership Questionnaire (MLQ) and the Teacher's Sense of Efficacy Scale (TSES) to garner data for analysis. Pearson's correlation coefficient and stepwise regression analyses were used in SPSS for data analyses. Results indicate that while 'idealised influence' and 'intellectual stimulation' accounted for the highest variation in teachers' sense of efficacy (predicting 32.1\% of teacher sense of efficacy), 'idealised influence' was found to account for the variations in 'teacher efficacy in student engagement' (Mehdinezhad and Mansouri, 2016: 54). Their analyses can be described at best, as very limited, failing to ascertain the impact of factors of principals' transformational leadership on the three factors of teachers' sense of efficacy.

The more recent study conducted by Gkolia and colleagues (2018) also used a sample size of 640 teachers from elementary and secondary school in Greece. The PLQ and the TSES were used for data collection. Data was analysed using multilevel structural equation modelling techniques (SEM). Though the analyses provided comprehensive tables and figures on the relationship between the two variables, there was little or no interpretations and discussions of the results of the analyses. For Gkolia and colleagues (2018), the 4 selected factors of principals' transformational leadership behaviours (model behaviour, fosters commitment, provide intellectual stimulation and holds high performance expectations) significantly related to teachers' sense of efficacy in student engagement (p.190). The effect size of the impact is not indicated in the study.

In consequence, while higher teacher efficacy in student engagement facilitates teaching and learning and motivates students to develop higher levels of expectations and self-belief, literature in the area is very limited. While most of the reviewed studies in the area indicate that various elements of principals' transformational leadership practices significantly relate to this subscale of teachers' sense of efficacy (Ryan, 2007; Ling et al., 2015; Mehdinezhad and Mansouri, 2016, Shumate, 2013, Short, 2016; Gkolia et al., 2018), very few studies investigate the degree of impact principals' transformational leadership have on teachers' sense of efficacy in student engagement.

\subsubsection{Teachers' Sense of Efficacy in Instructional Strategies}

Teacher Efficacy in instructional strategies entails teachers' beliefs in their ability to respond to difficult questions from students, gauge students' comprehension of what has been taught, craft good questions for students, adjust lessons to suit students' abilities, use alternative explanations or examples to enable student understanding, use different assessment strategies, and provide appropriate challenges for very capable students (see, TschannenMoran et al., 2001: 800). In other words, it focuses teachers' abilities to organise instructional programs and achieve desired outcomes (Tschannen-Moran et al., 2001; Ross and Bruce, 2007; Gavora, 2010). Ross and Bruce (2007) reported that teachers with such higher efficacy measures are 'more likely to try new teaching ideas, particularly techniques that are difficult, involve risk, and require that control is shared with students (p.50). Thus, to what extent do principals' transformational leadership practices impact on this efficacy variable?

In the quantitative study conducted by Espinoza (2013) in elementary and secondary schools in Texas, findings indicate that 'model best behaviour' and 'setting directions' were significantly related to teachers' sense of efficacy in instructional strategies - accounting for an overall $8 \%$ of the variance (see, ibid, p79). This meant that when principals increased their leadership practices of setting directions and modelling best behaviour, teachers' efficacy in instructional strategies also increase correspondingly.

Mehdinezhad and Mansouri's (2016) study of elementary, middle and secondary schools in Iran also found significant relationships between principal transformational leadership practices and teachers' efficacy in instructional engagement (p.54). While the researchers indicated that 'idealised influence; and 'intellectual stimulation' had overall positive statistically significant relationship between principals' leadership and teacher sense of efficacy, the study failed to indicate the degree of impact these leadership factors had on teachers' sense of efficacy in instructional strategies.

In the same way, Gkolia and colleagues' (2018) study of 640 elementary and secondary school teachers in Greece also indicated positive correlations between principals' transformational leadership practices and teachers' sense of efficacy in instructional strategies (p.189). While leadership practices such as: 'model behaviour', 'fosters commitment', 'individual support' and 'holds high performance expectations' correlated positively with teachers' 
sense of efficacy in instructional strategies, Gkolia and colleagues (2018) do not equally indicate the degree of impact of these leadership practices on teachers' sense of efficacy in instructional strategies.

In the case of Ling and colleagues (2015), they also used quantitative surveys to study the correlations between the 8 factors of the NSLS and the three factors of teacher sense of efficacy using 137 secondary school teachers in Malaysia. Surprisingly, the researchers did not analyse the relationship between domains of the independent and dependent variables. They only indicated that 'model behaviour' and 'provides individual support' significantly contributed to teacher efficacy in teaching (p.81). It is however unclear whether their reference to 'teacher efficacy in teaching' implies efficacy in instructional strategies or efficacy in general.

In consequence, while teachers' sense of efficacy in instructional strategies point to beliefs in their capability to organise instructional materials and achieve instructional outcomes, they reviewed literature supports the claim that various transformational leadership practices contribute to enhancing this teacher-effect variable. As a vital domain to teacher performance, it is known that mediatory factors such as teacher qualification, teacher continuous professional development and teacher motivation contributes to enhancing their efficacy in instructional strategies. Yet, principals' transformational leadership practices equally impact on this efficacy variable. What is limited in the literature is the availability of research studies that demonstrate the degree of impact of principals' transformational leadership practices on teachers' sense of efficacy in tertiary institutions.

2.3.3. Teachers' sense of efficacy in classroom management

Teachers' sense of efficacy in classroom management concerns teachers' beliefs in their ability to handle problems and disruptive behaviours in the classroom to ensure that the learning environment supports effective teaching and learning. It relates to the extent to which teachers believe that they have the capability to create the appropriate classroom conditions which support effective teaching and learning (Leithwood and Jantzi, 1999). Thus, it involves teachers' ability to respond to certain problems and disruptive behaviours in the classroom, their ability to get through to the most difficult student, help students think critically, help students believe in their capability and value learning (Tschannen-Moran, Woolfolk Hoy and Hoy, 2001).

Leithwood and Jantzi (1999) indicate that creating the appropriate classroom conditions for teaching and learning 'makes a substantially greater contribution to student achievements' (p457). In the study conducted by Ross and Bruce (2007), they found that teachers with high sense of efficacy always use classroom management strategies that stimulate student learning and student autonomy. They found that teacher efficacy in classroom management led to higher student achievement 'because those management strategies kept students on task more effectively than custodial management techniques' (Ross and Bruce, 2007: 50).

Since principal transformational leadership practices directly impacts on teacher-effect variables, to what extent, if at all, do principals' transformational leadership practices impact on teachers' sense of efficacy in classroom management? While findings from Espinoza's (2013) study indicated a positive statistically significance relationship between principals' transformational leadership behaviours and teachers' efficacy in classroom management, the leadership practice of 'setting directions' and 'redesigning the organisation' accounted for $10 \%$ of the variance in teacher efficacy in classroom management (see, Espinoza, 2013: 77).

There are other research studies which demonstrate the statistically significant relationships between principals' transformational leadership practices and teachers' sense of efficacy in classroom management (Ryan, 2007; Shumate, 2011; Ling et al., 2015; Short, 2016). While most of these studies indicate that leadership practices such as: ' 'setting directions', 'redesigning the organisation', 'providing individual support', 'inspirational motivation' significantly correlated with teachers' sense of efficacy in classroom management, what is however lacking in the literature is the availability of studies that demonstrate: (i) the degree to which these practices impact on teachers' sense of efficacy; and (ii) the specific leadership practice which impact the most on these teachers' sense of efficacy. This current study therefore investigates the relationship between these two key variables in the University `Colleges of Education in Ghana.

\section{Research Questions and hypotheses}

3.1. How much of the total variance of tutors' sense of efficacy in student engagement (SE) is explained by their perceptions of the transformational leadership practices of their college principals?

Ho1: Tutors' sense of efficacy in student engagement (SE) is not a function of their perceptions of the transformational leadership practices of their principals.

3.2. How much of the total variance in tutors' sense of efficacy in instructional strategies (IS) is accounted for by their perceptions of the transformational leadership practices of their college principals?

Ho2: Tutors' sense of efficacy in instructional strategies (IS) is not a function of their perceptions of the transformational leadership practices of their principals.

3.3. How much of the total variance of tutors' sense of efficacy in classroom management (CM) is explained by their perceptions of the transformational leadership practices of their college principals?

Ho3: Tutors' sense of efficacy in classroom management is not a function of their perceptions of the transformational leadership practices of their principals. 


\section{Research Methodology}

\subsection{Research Design}

The study is a descriptive and analytic survey, involving the use of the Principal Leadership Questionnaire (PLQ) and the Teacher Sense of efficacy Scale (TSES) to measure tutors' perceptions of leadership and their assessment of their self-efficacy beliefs. Cohen and colleagues (2016) indicate that descriptive surveys 'describe, compare, contrast, classify and interpret entities and events that constitute their various fields of inquiry' (p.257). They define the nature of prevailing conditions, practices, attitudes, perceptions and opinions that are held, processes that are on-going or trends that are developed. In this way, the study describes the impact of tutors' perceptions of leadership on their sense of efficacy.

The study is also an analytic survey because it involves the testing of hypotheses. Cohen and colleagues (2016) indicate that analytic surveys 'operate with hypothesised predictor or explanatory variables that are tested for their influence on dependent variables' (p.257). These tests are conducted to ascertain the extent to which the independent variable accounts for variances in the dependent. Here, tutors' perceptions of their principals' transformational leadership practices are tested to ascertain their moderating effects on their sense of efficacy in student engagement, instructional strategies and classroom management.

\subsection{Research Population and Sampling}

The research study was conducted in selected university colleges of education in Ghana. Thus, its target population was all tutors in the 43 public Colleges of Education in the country at the time. The estimated total number of tutors in these colleges at the time was about 1,700. Consequently, a representative sample of the target population was selected using cluster sampling procedures. Denscombe (2014) indicates that a representative sample involves the use of a cross-section of the population which matches the entire population in terms of its mix of ingredients. This sample is obtained by a selection procedure that: (i) includes all relevant factors; and (ii) matches proportions in the overall population' (Denscombe, 2014: 32).

To ensure that the sample was representative and generalizable, the study used cluster sampling methods and procedures. Cohen and colleagues (2016) indicate that cluster sampling is normally useful when the population is large and widely dispersed. At the time the study was conducted, there were 43 public colleges of education in the country. These colleges were spread across the 10 political and administrative regions of the country (with each region having at least two or more colleges). Thus, to study all the 1,700 tutors spread over a geographical area of 238,540 square kilometres proved to be cumbersome.

Consequently, 4 clusters (regions) were selected (i.e. Central, Eastern, Northern and Upper East Regions) for the study using random sampling procedures. Here, the name of each region/cluster was written on a piece of paper and placed in a box. The box was then shuffled, and each region selected after each shuffle until the four clusters/regions were obtained. In this way, all the ten regions/clusters together with all forty-three public colleges with each tutor in them had an equal chance of being selected. Hence, an estimated representative sample size of 629 tutors from fifteen selected colleges in the four regions was anticipated for the study.

\subsection{Instruments and Data Collection Procedures}

The Teacher Sense of Efficacy Scale (TSES) was used to garner data on tutors' assessments of their sense of efficacy in student engagement, instructional strategies and classroom management. The instrument was developed by Tschannen-Moran and Hoy (2001) to measure three efficacy subscales: efficacy in student engagement, instructional strategies and classroom management. The Alpha reliabilities for each subscale were: 0.90 for efficacy in student engagement; 0.91 for efficacy in instructional strategies; and 0.87 for efficacy in classroom management (see, Tschannen-Moran and Woolfolk Hoy, 2001:799). The instrument has a 9-point Likert scale ranging from: (1) Nothing; (3) Very Little; (5) Some Influence; (7) Quite a Bit; and (9) A Great Deal was used in this study. Table 1 shows the items distribution of the TSES following its three efficacy subscales.

Table 1: Item Distribution of the Teachers' Sense of Efficacy Scale.

TSES factors or subscales

\begin{tabular}{|l|l|}
\hline Efficacy in Student Engagement SE) & \multicolumn{1}{c|}{ Items } \\
\hline Efficacy in Instructional Strategies (IS) & $1,2,4,6,9,12,14,22$ \\
\hline Efficacy in Classroom Management (CM) & $7,10,11,17,18,20,23,24$ \\
\hline
\end{tabular}

To examine tutors' perceptions of their principals' transformational leadership practices, Jantzi and Leithwood's (1996) Principals' Leadership Questionnaire (PLQ) instrument was used. The PLQ contains twentyfour questionnaire items designed on six dimensions of transformational leadership practices. It has a 4-point Likert scale ranging from Strongly Disagree (1) to Strongly Agree (4). See table 2 for the item distribution of the instrument. 
Table 2: Item Distribution of the Principal Leadership Questionnaire.

\begin{tabular}{|c|c|}
\hline PLQ Dimensions & Items \\
\hline Provides Vision (PV) & $1,2,3,4,5$ \\
\hline Models Behaviour (MB) & $6,7,8$ \\
\hline Fosters Commitment (FC) & $9,10,11,12,13$ \\
\hline Provides Individual Support (IS) & $14,15,16,17,18$ \\
\hline Provides Intellectual Stimulation (NS) & $19,20,21$ \\
\hline Holds High Performance Expectation (HE) & $22,23,24$ \\
\hline
\end{tabular}

In relation to the validity and reliability of the instrument, Cronbach Alpha yielded strong reliability coefficient of 0.91 , with a range from 0.73 to 0.88 for all six dimensions of transformational leadership behaviours (see, Jantzi and Leithwood, 1996: 524). Thus, tutors were asked to rate the leadership practices of their principals in relation to the following six leadership factors: provides vision (PV), fosters commitment (FC), provides individual support (IS), provides intellectual stimulation (NS), models behaviour (MB), and holds high performance expectation (HE).

In consequence, paper-pencil questionnaire comprising the PLQ and TSES items were personally distributed to the 629 tutors from the 15 selected colleges in the 4 selected regions/clusters (that is, Central, Eastern, Northern and Upper East Regions). In each of the colleges visited, personal contacts were made to principals who supported the process. Tutors were informed about the rationale for the research and their contribution to it. Tutors were also informed about their freedom to opt out of the research at any stage of the study. Thus, out of the 629 questionnaires that were distributed, 444 were completed and returned representing a response rate of $70.5 \%$. However, about 10 responses were rejected due to the incompletion of some items. Thus, an overall valid response rate of $68.9 \%$ (434 responses) was obtained for the analysis.

\section{Data Analysis Procedures}

Raw survey data which consisted of item-by-item responses by tutors in the TSES and PLQ instruments were first entered into Excel spreadsheet and then exported to SPSS version 26 (MAC) to establish descriptive and inferential statistics. SPSS was also used establish the test of normality and the reliability of the instrument. These needed to be established to allow for inferential statistics.

Previous studies on normality test confirmed that with large enough sample sizes ( $>30$ or 40$)$, the violation of the normality assumption should not cause major problems (Pallant, 2007) and that the sampling distribution tends to be normal, regardless of the shape of the data (Field, 2009; Elliot \& Woodward, 2007). This implied that parametric procedures could be applied with samples consisting of hundreds of observations (Elliot \& Woodward, 2007; Altman \& Bland, 1995). However, the test of normality of the TSES and PLQ found the items to be negatively skewed. Thus, $\log 10$ linear transformation was applied in SPSS to establish normality for parametric purposes.

The Cronbach alpha reliability was used to examine the reliability of the instruments for this study. Checking the reliability of the instrument used provides statistical confident for using the analyses of data in answering research questions and testing the formulated hypotheses. The Cronbach alpha provides a measure of the internal consistency of a test or scale. It is expressed as a number between 0 and 1 . Research studies show that reliability values ranging from 0.70 and above are sufficient for conducting statistical analyses (Gall and Gall, 2003; Hair et al., 2010). Internal consistency normally describes the extent to which all the items in a test measure the same concept or construct (Cohen et al., 2016).

Consequently, the results of the Cronbach alpha reliability analysis of TSES were between 0.80 to 0.93 , revealing that all items met the threshold of 0.70 and above. The composite reliabilities recorded high accepted values $0.85,0.92$ and 0.86 for efficacy in student engagement, instructional strategies and classroom management respectively. The results of the Cronbach alpha reliability analysis for factors of the PLQ also revealed values ranging from 0.75 to 0.87 ; revealing that the items were valid for the study. Composite reliabilities also recorded accepted values such as: $\mathrm{PV}=0.86, \mathrm{MB}=0.85, \mathrm{FC}=0,87, \mathrm{ISL}=0.83, \mathrm{NS}=0.77$ and $\mathrm{HE}=0.75$. In this way, univariate and bivariate analyses were conducted to establish the descriptive and inferential statistics such as means and standard deviations, correlation and regression analyses.

\section{Results of the Analyses}

6.1. Descriptive Statistics

6.1.1. Gender, Academic Qualification and Experience

From a total of 434 tutors who participated in the study, $318(73.3 \%)$ were male and $116(26.7 \%)$ female. This implied that more male tutors participated in the survey as compared to females. In terms of their academic qualifications, while $3(0.7 \%)$ tutors obtained diplomas, 29 (6.7\%) obtained first degrees and $3(0.7 \%)$ obtained PhDs. However, a considerable number of 399 (91.9\%) tutors obtained masters or MPhil degrees which is the recommended minimum level of qualification for tutors in these colleges. This implies that most of the tutors in 
the studied colleges of education met the minimum qualification for teaching in the studied colleges.

The descriptive statistics of tutors' years of experience and their years of work with their current principals indicate that the minimum number of years of work as a tutor is 1 while maximum is 35 . The minimum number of years with which tutors worked with their current principals was 1 and the maximum was 22. So, while the average years of experience as a tutor was 9, the average work experience with current principal was 4.

6.1.2. Tutors' Sense of Efficacy

The TSES instrument was used to assess tutors' self-efficacy beliefs in three areas: efficacy in student engagement, instructional strategies and classroom management. Tutors responded to each of the twenty-four items on a 9point Likert scale ranging from 1(nothing) to 9 (a great deal). In this way, the higher the ratings, the greater the self-efficacy beliefs of tutors. While ratings from 1 to 5 (meaning 'nothing' to 'very little') demonstrate lower selfefficacy belief, ratings from 6 to 9 (meaning 'quite a bit' to 'a great deal') show higher tutor scores in their selfefficacy beliefs.

The overall mean score of the self-efficacy beliefs of tutors in the 15 colleges was $(M=7.21, S D=1.13)$. This implied that tutors rated themselves to have high sense of efficacy. However, while efficacy in student engagement recorded $(\mathrm{M}=7.07, \mathrm{SD}=1.07)$, efficacy in instructional strategies recorded $(\mathrm{M}=7.37, \mathrm{SD}=1.18)$ and efficacy in classroom management obtained $(\mathrm{M}=7.19, \mathrm{SD}=1.14)$. These values equally indicate that tutors in the studied colleges of education in Ghana have high sense of efficacy. It can be seen that tutors' sense of efficacy in instructional strategies (IS) obtained the highest value $(M=7.37, S D=1.18)$.

6.1.3. Tutors' Perceptions of Leadership

The Principal Leadership Questionnaire (PLQ) was used to measure tutors' perceptions of their principals' transformational leadership practices. Tutors' perceptions were measured against the backdrop of the following six factors of the PLQ: provides vision (PV), models behaviour (MB), foster commitment (FC), provides individual support (ISL), provides intellectual stimulation (NS) and holds high performance expectations (HE). Following a 4-point Likert scale, the higher the ratings, the more tutors considered their principals' leadership practices to be transformational.

Consequently, the overall average mean score of tutors' perceptions of their principals' leadership practices was $(M=3.02, S D=0.57)$; indicating that tutors agreed that their principals' leadership practices were transformational. The mean score for each of the six factors of principals' leadership practices obtained the following: provides vision $(M=3.03, S D=0.59)$, modelling best behaviour $(M=3.05, S D=0.64)$, fosters commitment $(M=3.05, S D=0.57)$, providing individual support $(M=2.87, S D=0.57)$, intellectual stimulation $(M=2.92, S D=0.57)$ and holds high performance expectations $(M=3.24, S D=0.54)$.

\subsection{Correlational Analyses}

Pearson's product moment coefficient of correlation with measures of association which range from -1.0 to 1.0 was used. Cohen's (1988; cited in Pallant, 2010) indicates that the magnitude of correlations ranges from: $r=-1.0$ to 0.29 (small); $r=0.30$ to 0.49 (medium); $r=0.50$ to 1.0 (large). Thus, while the correlation coefficient (the $R$ value) demonstrates the strength or magnitude of the relationship, statistical significance (the $p$-value) is distinguished by an asterisk at 0.05 levels and a double asterisk at 0.01 levels. As Cohen and colleagues (2016) indicated, 'the greater the sample size, the lower the correlation coefficient has to be in order to be statistically significant' (p.634). Correlational analyses were conducted in this study to ensure that there are linear relationships between factors of the dependent and those of independent variables. Ensuring such linearity is part of the fundamental assumptions for conducting multiple regression analysis (see, Gorard, 2001: 213; Pallant 2007: 148; Cohen et al., 2016: 668-9).

\subsubsection{Transformational Leadership and Efficacy in Student Engagement}

Using the Pearson product moment correlation coefficient, a statistically significant correlation was found between tutors' sense of efficacy in student engagement (SE) and five principal leadership practices such as: provides vision $(r=.188, p=0.000)$; foster commitment $(r=.128, p=.008)$; provides individual support $(r=.152, p=.001)$; intellectual stimulation $(r=.112 . p=.020)$; and holds high performance expectations $(r=.160, p=.001)$.

Without the implications of causality, the results implied that there were linearity between principals' transformational leadership practices such as: providing vision, fostering commitment, providing individua support, intellectual stimulation and holding high performance expectations and tutors' sense of efficacy in student engagement. However, the results did not find statistically significant relationship between tutors' sense of efficacy in student engagement and principals' transformational leadership practice of modelling best behaviour $(r=.083$, $p=.085)$.

6.2.2. Transformational Leadership and Efficacy in Instructional Strategies

The results found statistically significant relationships between tutors' sense of efficacy in instructional strategies and three principals' transformational leadership practices such as: provides vision $(r=.112, p=.020)$; provides individual support $(r=.101, p=.035)$; and holds high performance expectations $(r=.130, p=.007)$.

These results thus implied that principals' transformational leadership practices such as provide vision, 
provide individual support and hold high performance expectations, positively related to tutors' sense of efficacy in instructional strategies. However, principals' transformational leadership practices such as: model best behaviour ( $r=.043, p=.369)$; fosters commitment $(r=.063, p=.118)$; and provides intellectual stimulation $(r$ $=.037, p=.436$ ) did not find statistically significant relationship with tutors' sense of efficacy in instructional strategies.

6.2.3. Transformational Leadership and Efficacy in classroom Management

Using Pearson product moment correlation coefficient, statistically significant relationships were found between tutors' sense of efficacy in classroom management and four principal leadership practices such as: provides vision $(r=.166, p=.001)$ : fosters commitment $(r=.127, p=.008)$; provides individual support $(r=.148, p=.002)$; and holds high performance expectation $(r=.135, p=.005)$.

Whereas the relationship was positive, the magnitude was small following Cohen's (188) rule of thumb. However, principals' transformational leadership practices such as modelling best behaviour $(r=.077, p=.111)$ and provides intellectual stimulation $(r=.093, p=.053)$ did not find statistically significant relationships with their sense of efficacy in classroom management.

\subsection{Regression Analyses}

Multiple regression analyses were used here because it enabled the researcher to take in a range of independent variables and calculate their relative effects or weightings on the dependent variable (Cohen et al., 2016:664). Multiple regression analysis was therefore conducted to test three hypothesized relationship between tutors' sense of efficacies in student engagement, instructional strategies and classroom management and the transformational leadership practices which significantly correlated with these efficacy factors. In this way, the analyses below presents responses to the stated research questions and hypotheses.

6.3.1. How much of the total variance of tutors' sense of efficacy in student engagement (SE) is explained by their principals' transformational leadership practices of: providing vision (PV), fostering commitment (FC), providing individual support (ISL), intellectual stimulation (NS) and holding high performance expectations (HE)?

Hol: Tutors' sense of efficacy in student engagement (SE) is not a function of their principals' transformational leadership practices.

In response to this research question and null hypothesis (Ho1), multiple regression analysis was conducted using the above dependent variable (SE) and the following independent variables (PV, FC, ISL, NS, and HE). The obtained values between the dependent variable $(\mathrm{SE})$ and the independent variables $(R=.237)$ as shown in table 3 was statistically significant $F(6,427)=4.237, P<.000$. The data therefore did not support the null hypothesis (Ho1) on the basis of the leadership practice of providing vision $(p=.002)$. While the derived $\mathrm{R} 2$ shows that principals' transformational leadership practices accounted for $5.6 \%$ of the total variance in tutors' sense of efficacy in student engagement, the adjusted R2 is $4.3 \%$.

Table 3: Regression Analysis of Full Model between Student Engagement and Leadership Practices of College Principals.

\begin{tabular}{lllcccc}
\hline \hline Model & $\mathrm{R}$ & $\mathrm{R} 2$ & Adjusted R2 & $\mathrm{df}$ & $\mathrm{F}$ & $\mathrm{P}$ \\
\hline $\begin{array}{l}\text { Student } \\
\text { Engagement }\end{array}$ & .237 & .056 & .043 & 6,427 & 4.237 & $.000^{\mathrm{b}}$ \\
\hline \hline
\end{tabular}

Predictors: (Constant), PV, MB, FC, ISL, NS, and HE. b. Dependent Variable: SE. P <.05

Table 4: Beta Coefficients Between Student Engagement and Six Leadership Practices.

\begin{tabular}{lccccr}
\hline & \multicolumn{2}{c}{ Unstandardized Coefficients } & Standardized Coefficients & & \\
\cline { 2 - 5 } Model & Beta & Std. Error & Beta & Sig. \\
\hline 1(Constant) & .369 & .021 & & 17.598 .000 \\
Provides Vision & .341 & .111 & .293 & 3.061 & .002 \\
Fosters Commitment & -.084 & .113 & -.071 & -.745 & .457 \\
Individual Support & .114 & .105 & .089 & 1.092 & .275 \\
Intellectual Stimulation & -.021 & .090 & -.018 & -.238 & .812 \\
High Performance Exp. & .111 & .075 & .095 & 1.488 .137 \\
\hline \hline
\end{tabular}

$\mathrm{P}<.05$. Adjusted R2 $=0.43, F(55,427)=4.237, P<.001$. adjusted $\mathrm{R}$ square $=4.3$

Table 4 shows the unstandardized and standardized beta coefficients of each component variable. Using the unstandardized beta coefficients, one observes that, relative to each other, provides vision $(\beta=.341, \rho=.002)$ exerted the greatest influence on tutors' sense of efficacy in student engagement. The derived multiple regression value for the model of best fit and tutors' sense of efficacy in student engagement $R=.188$ as shown in table 5 
was considered statistically significant $F(1,432)=15.865, P<.01$. The adjusted R2 .033 demonstrates that principals' leadership practices of providing vision accounted for about $3.3 \%$ of the variability in the full model $4.3 \%$. In this way, it could be said that the principal leadership practice of providing vision impacted more on tutors' sense of efficacy in student engagement.

Table 5: Regression Analysis of Model of Best Fit between Student Engagement Principal Leadership Practices.

\begin{tabular}{lcccccc}
\hline \hline Model & $\mathrm{R}$ & $\mathrm{R} 2$ & Adjusted R2 & $\mathrm{df}$ & $\mathrm{F}$ & $\mathrm{P}$ \\
\hline Student Engagement & $.188^{\mathrm{a}}$ & .035 & .033 & 1,432 & 15.865 & .000 \\
\hline \hline
\end{tabular}

a. Predictors: (Constant), PV b. Dependent Variable: SE. P $<.05$

6.3.2. How much of the total variance in tutors' sense of efficacy in instructional strategies (IS) is accounted for by perceptions of their principals' transformational leadership practices of providing vision (PV), individual support (ISL) and holding high performance expectation (HE)?

Ho2: Tutors' sense of efficacy in instructional strategies (IS) is not a function of their principals' transformational leadership practices.

The derived multiple regression value $R=.186$ as shown in table 6 is viewed to be statistically significant $F(6$, 427 ) $=2.563, P=.019$. The null hypothesis (ho11) was therefore not supported. The value of adjusted R2=.021 in the analysis indicates that principals' leadership practices accounted for about $2.1 \%$ of the total variance in tutors' sense of efficacy in instructional strategies.

Table 6: Regression Analysis between Efficacy in Instructional Strategies and Principals' Leadership Practices.

\begin{tabular}{lcccccc}
\hline \hline Model & $\mathrm{R}$ & $\mathrm{R} 2$ & Adjusted R2 & $\mathrm{df}$ & $\mathrm{F}$ & $\mathrm{P}$ \\
\hline Instructional Strategies & $.186^{\mathrm{a}}$ & .035 & .021 & 6,427 & 2.563 & $.019^{\mathrm{b}}$ \\
\hline \hline
\end{tabular}

a. Predictors: (Constant), PV, MB, FC, ISL, NS, and HE. b. Dependent Variable: IS. $\mathrm{P}<.05$

Table 7: Beta Coefficients between Efficacy in Instructional Strategies and Principals' Leadership Practices.

\begin{tabular}{lcccr}
\hline \hline & \multicolumn{2}{l}{ Unstandardized Coefficients } & Standardized Coefficients & \\
\cline { 2 - 5 } Model & Beta & Std. Error & Beta & Sig. \\
\hline 1(Constant) & .334 & .024 & & 13.953 .000 \\
Provides Vision & .228 & .127 & .173 & 1.794 .074 \\
Individual Support & .181 & .120 & .125 & 1.515 .130 \\
Holds High Performance Expectation & .180 & .085 & .136 & 2.108 .036 \\
\hline \hline
\end{tabular}

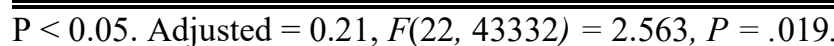

Table 7 shows the unstandardized and standardized beta coefficients of each component variable. Using the unstandardized beta coefficients, it was observed that relative to each other, the only variable which impacted on tutors' sense of efficacy in instructional strategies was the leadership practice of holding high performance expectation $(\beta=.180, \rho=.036)$. The leadership practices of providing vision and individual support exerted small but statistically nonsignificant effects on the dependent variable $(\beta=.228, \rho=.074$ and $\beta=.181, \rho=.130$ respectively).

However, the value for the model of best fit and tutors' sense of efficacy in instructional strategies $(R=.130)$ as shown in table 8 is considered statistically significant $F(1,432)=7.398, P=.007$. The adjusted R2 (.015) demonstrates that principals' leadership practices of holding high performance expectations accounted for about $1.5 \%$ of the variance in the full model $(2.1 \%)$.

Table 8: Regression Analysis of Model of Best Fit between Instructional Strategies and Transformational Leadership practices.

\begin{tabular}{lccccccc}
\hline \hline Model & $\mathrm{R}$ & $\mathrm{R} 2$ & Adjusted R2 & $\mathrm{df}$ & $\mathrm{F}$ & $\mathrm{P}$ \\
\hline Instructional Strategies & $.130^{\mathrm{a}}$ & .017 & .015 & 1,432 & 7.398 & $.007^{\mathrm{b}}$ \\
\hline \hline
\end{tabular}

a. Predictors: (Constant), HE. b. Dependent Variable: IS. $\quad \mathrm{P}<.05$

6.3.3. How much of the total variance of tutors' self-efficacy in classroom management (CM) is explained by perceptions of their principals' transformational leadership practices of 'provides vision (PV), fosters commitment' (FC), provides individual support (ISL) and holds high performance expectations (HE)?

Ho3: Tutors' sense of efficacy in classroom management is not a function of their perceptions of the transformational leadership practices of their principals.

The results of multiple regression analysis as shown in table 9 was significant $F(6,427)=3.225, p=.004$. So, the null hypothesis (Ho3) was rejected. The value of adjusted R2 (.030) in the analysis indicated that principals' transformational leadership practices accounted for about $3.0 \%$ of the total variance in tutors' sense of efficacy in classroom management. 
Table 9: Regression Analysis between Efficacy in Classroom Management and Principals' Leadership Practices.

\begin{tabular}{lcccccc}
\hline \hline Model & $\mathrm{R}$ & $\mathrm{R} 2$ & Adjusted R2 & $\mathrm{df}$ & $\mathrm{F}$ & $\mathrm{P}$ \\
\hline Classroom Management & $.208^{\mathrm{a}}$ & .043 & .030 & 6,427 & 3.225 & $.004^{\mathrm{b}}$ \\
\hline \hline
\end{tabular}

a. Predictors: (Constant), PV, MB, FC, ISL, NS and HE. b. Dependent Variable: CM. P $<.05$

Table 10: Beta Coefficients between Efficacy in Classroom Management and Principals' Transformational Leadership Practices.

\begin{tabular}{|c|c|c|c|c|c|}
\hline \multirow[b]{2}{*}{ Model } & \multicolumn{2}{|c|}{ Unstandardized Coefficients } & \multirow{2}{*}{$\begin{array}{r}\text { Standardized } \\
\text { Coefficients } \\
\text { Beta }\end{array}$} & \multirow[b]{2}{*}{$\mathrm{t}$} & \multirow[b]{2}{*}{ Sig. } \\
\hline & Beta & Std. Error & & & \\
\hline 1 (Constant) & .347 & .023 & & 15.344 & .000 \\
\hline Provides Vision & .276 & .120 & .222 & 2.303 & .022 \\
\hline Fosters Commitment & -.013 & .122 & -.010 & -.108 & .914 \\
\hline Individual Support & .158 & .113 & .115 & 1.404 & .161 \\
\hline $\begin{array}{l}\text { Holds High Performance } \\
\text { Expectation }\end{array}$ & .087 & .081 & .069 & 1.078 & .282 \\
\hline
\end{tabular}

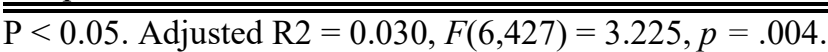

Table 10 shows the unstandardized and standardized beta coefficients of each component variable. Using the unstandardized beta coefficients, it is observed that relative to each leadership factor, the practice of providing vision positively impacted on tutors' sense of efficacy in classroom management $(\beta=.276, \rho=.022)$. The derived multiple regression value for the model of best fit $(R=.166)$ as shown in table 11 is considered statistically significant $F(1,432)=12.184, P=.001$. The adjusted R2 (.025) demonstrates that principals' leadership practices of providing vision (PV) accounted for about (2.5\%) of the variance in the full model $(3.0 \%)$.

Table 11: Regression Analysis of Model of Best Fit between Classroom Management and Transformational Leadership practices.

\begin{tabular}{lcccccc}
\hline \hline Model & $\mathrm{R}$ & $\mathrm{R} 2$ & Adjusted R2 & df & F & $\mathrm{P}$ \\
\hline $\begin{array}{l}\text { Classroom } \\
\text { Management }\end{array}$ & $.166^{\mathrm{a}}$ & .027 & .025 & 1,432 & 12.184 & $.001^{\mathrm{b}}$ \\
\hline \hline
\end{tabular}

a. Predictors: (Constant), PV

b. Dependent Variable: $\mathrm{CM} \quad \mathrm{P}<.05$

\section{Discussion of Findings}

7.1. Leadership Practices that Impact on tutors' efficacy in student engagement

Under tutors' sense of efficacy in student engagement, the analyses in chapter four ascertained the extent to which the total variance in tutors' efficacy in this area was explained by their perceptions of the transformational leadership practices of their college principals. The results of the analysis indicated that principals' transformational leadership practices accounted for about $4.3 \%$ of the total variance in tutors' sense of efficacy in student engagement. The leadership practice of providing vision accounted for $3.3 \%$ of the total variance. This finding therefore implied that the more principals exercised the transformational leadership practice of providing vision, the better they enhance their tutors' sense of efficacy in student engagement.

In contrast to findings of the reviewed studies in the area (Ryan, 2007; Shumate, 2011; Espinoza, 2013; Ling et al., 2015; Mehdinezhad and Mansouri, 2015; Short, 2016; and Gkolia et al., 2018), whereas most of these studies did not conduct regression analyses on the relationship between the two variables, some of the studies also deselected teachers' sense of efficacy in student engagement on the basis of factorial extractions. For instance, while Ryan (2007) did not conduct regression analysis to ascertain the predictability of principals' leadership practices on teachers' sense of efficacy in student engagement, Shumate (2011) too did not conduct such analyses, and so did Short (2016).

Espinoza's (2013) study used SEM to examine the extent to which the total variance in teachers' sense of efficacy is accounted for by their principals' transformational leadership practices. However, Espinoza's (2013) study used of exploratory factor analysis (EFA) led to the deselection some factors of principals' transformational leadership practices and teachers' efficacy in student engagement. Hence, the relationship was not examined in the study. Ling and colleagues (2015) also performed multiple regression analyses in their study. But their analyses were limited because they only focused on the relationship between teachers' sense of efficacy in general and factors of principals' transformational leadership practices.

Similarly, Mehdinezhad and Mansouri (2015) also conducted a stepwise regression analyses which only identified idealised influence and intellectual stimulation as principals' leadership practices which predicted $32.1 \%$ 
of the total variance in teachers' sense of efficacy in general (p.54). Teachers' sense of efficacy in student engagement was not considered in the analyses. In Gkolia and colleagues' (2018) study of elementary and secondary school teachers in Greece, their analyses also indicated that the general factors of principals' transformational leadership practices predicted $9.0 \%$ of the variance in teachers' efficacy in student engagement (Gkolia et al., 2018: 189).

While the result of this current study is consistent with those of Gkolia and colleagues' (2018) on the basis of the understanding that principals' leadership practices impacted on teachers' sense of efficacy in student engagement, the percentages of variances between the two studies differed significantly. This could be due to the fact that this current study analysed the predictability of tutors' sense of efficacy in student engagement based on the individual factors of principals' transformational leadership practices. Gkolia and colleagues (2018) however performed their analysis on the basis of how the general factors of principals' transformational leadership practices predicted teachers' efficacy in student engagement.

Consequently, the finding of this study is unique and relevant in that: (1) within the wealth of extant literature in the area, only this current study demonstrates that principals' transformational leadership practice of providing vision impacts on tutors' sense of efficacy in student engagement in the studied colleges of education in Ghana. The scarcity of studies in this area therefore demonstrates distinctiveness and relevance of this current study to the literature in this area. In this way, principals who know that their leadership practice of providing vision positively influences tutors' efficacy in student engagement, can exercise this leadership practice as a means of enhancing their tutors' abilities to create the sort of tutor-student relationships which support effective teaching and motivate student learning.

\subsection{Leadership Practices that Impact on tutors' efficacy in instructional strategies}

Whereas tutors' sense of efficacy in instructional strategies refers to tutors' beliefs in their ability to organise appropriate instructional programmes and achieve desired instructional outcomes, this efficacy factor obtained the highest mean score in the analysis on tutors' assessments of their sense of efficacy. Following the review of literature in the area, studies show that teachers with high sense of efficacy in instructional strategies are more likely to be effective than those with low sense of efficacy (Tschannen-Moran and Woolfolk Hoy, 2001; Ross and Bruce, 2007: 50; Ross and Gray, 2006). Consequently, if tutors in this study rated themselves to have high sense of efficacy in instructional strategies and rated their principals to practice transformational leadership, then how much of the total variance in their sense of efficacy in instructional strategies is explained by their principals' transformational leadership practices?

Findings of this study indicated that while the identified principals' transformational leadership practices explained about $2.1 \%$ of the variability in tutors' sense of efficacy in instructional strategies, the specific leadership practice of holding higher performance expectations accounted for $1.5 \%$ of the total variance. This result suggested that the more principals exercised the leadership style of holding higher performance expectations in the studied colleges of education, the more tutors were likely to develop their sense of efficacies in instructional strategies. The leadership practice of holding higher performance expectations involves principals' actions such as: insistence on best performance from tutors; reminding tutors of the higher expectations that are expected of them as professionals; and letting tutors know that second best performance will not be tolerated (Jantzi and Leithwood, 1996: 534).

Within the wider context of research studies in the area (e.g. Ryan, 2007; Espinoza, 2013; Shumate, 2011; Ling et al., 2015; Mehdinezhad and Mansouri, 2015; Short, 2016; and Gkolia et al., 2018), it was observed that none of these studies examined the relationship between these variables except the studies conducted by Espinoza (2013) and Gkolia and colleagues (2018). In Espinoza's (2013) study, while findings indicated that principals influenced their teachers' sense of efficacy through leadership practices such as setting directions, holding high performance expectations and providing individual support, the practice of setting directions (or providing vision) accounted for about $8.0 \%$ of the total variance in teachers' efficacy in instructional strategies (see, Espinoza, 2013: 90-91). In Gkolia and colleagues' (2018) study, the general factors of principals' transformational leadership accounted for $8.0 \%$ of the total variance in teachers' sense of efficacy in instructional strategies (p.189).

Although consistent with the findings of this current study, the degrees of impact (8\%) as found in Espinoza's (2013) and Gkolia and colleagues' (2018) are by contrast larger than those of this study (1.5\%). Whereas Gkolia and colleagues' (2018) used all the factors of transformational leadership to predict teachers' efficacy in instructional strategies, it is also important to note that in Espinoza's (2013) study, the leadership practices of setting directions and providing individual support other than 'holding high performance expectations' predicted $7.0 \%$ of the variance in teachers' sense of efficacy in instructional strategies.

The reason for the stark differences in the percentage of impact in the findings of this current study and Espinoza's (2013) study could be due to the differences in institutional context. Espinoza (2013) conducted his study in elementary and secondary schools. Principals in elementary and secondary schools are more likely to have direct effects on their teachers' instructional strategies because of the relatively small sizes of these schools. The 
small size of a school (in terms of its population) allow for direct daily encounters between students, teachers and principals. Such direct daily encounters create opportunities for principals to influence teachers in their respective tasks. Secondly, principals of basic schools also have relatively shared expertise in the curriculum of the school, and hence, can provide instructional support and leadership to teachers through instructional supervision, the provision of feedback and the resources teachers need for effective teaching. This explained why Jantzi and Leithwood (1996: 522) observed that small schools offer greater opportunities for teachers and school leaders to work together closely and thus, provide teachers with the evidence necessary to form perceptions of leadership.

The situation is however different in tertiary institutions which are relatively bigger with complex administrative systems. Within tertiary institutions like the colleges of education in Ghana, principals may not possess the sort of tutor professional expertise that support effective and efficient delivery of instructional tasks. Principals in these colleges only play administrative roles as heads of institutions, and do not have direct daily classroom encounters with tutors. In this way, the degree of their leadership effects on tutors' efficacy in instructional strategies is limited in contrast to those in elementary, middle and secondary schools. Yet, the understanding that principals' leadership practice of holding high performance expectations impacted on tutors' sense of efficacy in instructional strategies in the studied colleges of education, albeit the degree, was in itself unique and significant. Thus, principals who know that their leadership practice of holding high performance expectations contributes about $1.5 \%$ in enhancing their tutors' efficacy in instructional strategies, may align their leadership practices in this way as means of facilitating tutor efficacy in this area.

\subsection{Leadership Practices that Impact on tutors' efficacy in classroom management}

While tutors' sense of efficacy in classroom management concerns the extent to which they belief in their ability to create the appropriate classroom environment that support effective teaching and learning, this efficacy factor involves tutors' beliefs such as: 'their ability to control disruptive behaviours in the classroom; make known to students expectations of good classroom behaviour; establish routines to ensure smooth running of classroom activities; get students to follow classroom regulations; keep problem students from ruining class activities; and effectively responding to defiant students' (Tschannen-Moran and Hoy, 2001).

In the analysis on tutors' assessments of their sense of efficacy in this study, efficacy in classroom management obtained the second highest mean score. By implication, this suggested that tutors in the studied colleges of education believed in their ability to create the classroom environment which support and sustain effective teaching and learning. This is vital because Leithwood and Jantzi (1999: 457) indicated that teachers make substantial contribution to student learning and academic achievements through their ability to create the appropriate classroom conditions that support effective teaching and learning. If tutors in these studied colleges rated themselves to be above average in their sense of efficacy in classroom management, then do their principals' transformational leadership practices contribute to enhancing this efficacy variable?

Findings of the study indicated that principals' transformational leadership practices accounted for 3\% of the total variance in tutors' sense of efficacy in classroom management. Out of this percentage, the practice of providing vision accounted for $2.5 \%$ of the variance. Situating these findings within the context of extant research studies in the area (Ryan, 2007; Espinoza, 2013; Shumate, 2011; Ling et al., 2015; Mehdinezhad and Mansouri, 2015; Short, 2016; and Gkolia et al., 2018), none of the studies performed analyses of this nature except the study conducted by Espinoza (2013). Findings from Espinoza's (2013) study indicated that 10\% of the total variance in teachers' efficacy in classroom management was explained by their principals' transformational leadership practices of setting direction and redesigning the organisation (Espinoza, 2013: 77). The practice of setting directions/providing vision however accounted for $9.0 \%$ of the total variance.

In this way, the result of this current study was to some extent consistent with that of Espinoza's (2013) study, albeit the differences in the degrees of impact which could be attributed to the differences in institutional context in which each research was conducted. The consistency of findings is derived from the fact that both studies identified the leadership practice of setting directions/providing vision as consequential. As mentioned earlier, the institutional size and context sometimes determine the extent to which principals' transformational leadership practices influence teachers' performance (see, Jantzi and Leithwood, 1996: 520). Tertiary institutions always operate within complex administrative structures in contrast to elementary and high schools.

For instance, the organogram of leadership in the colleges of education in Ghana is a complex one. It has the principal of the college, followed by two vice principals (academic and administration), different faculty or departmental heads. Within the teaching staff, there are different ranks as well: chief tutor, principal tutor, senior tutor and tutor (see, The Harmonised Scheme of Service for Colleges of Education in Ghana, 2013). This different administrative structure reflects a chain of leadership which rarely support direct principal-tutor leadership relationships at the classroom level. Besides, tutors of these colleges are also professionals who hold unique expertise in their respective fields. So, principals may not have the expertise to influence tutors' classroom management practices, the complex administrative character of these colleges do not also support direct principal leadership interventions in classroom management. Hence, the understanding that their leadership practice of 
providing vision accounted for $2.5 \%$ of the variance in tutors' efficacy in classroom management was significant as it may provide leadership guidance to principals in respect of tutors' sense of efficacy in classroom management.

\section{Implications of the Study}

First of all, the perceptions principals have about their own leadership practices and how these influence tutors' performance and contribute to achieving college goals may not always be coterminous with the perceptions of their tutors. Where this state affair exists, it could create the principal-tutor disengagements which impede the sort of productive relationships that support principal-tutor collaborative efforts in response to college goals. This study therefore offers to principals, tutors' views about their transformational leadership practices and how these impact on their performances. The results of this study can therefore help principals foster better leadership relationships with their tutors as an effective means to enhancing their performance.

Secondly, the establishment of strong positive statistically significant relationships between all three factors of tutors' sense of efficacy and most of the of the factors of principals' transformational leadership practices implied linear variations between them. Thus, this study together with extant research findings showed that there are positive statistically relationships between principals' transformational leadership practices of providing vision, fostering commitment, providing individual support, intellectual stimulation and holding high performance expectations and tutors'/teachers' sense of efficacy in student engagement, instructional strategies and classroom management. Since high high students' performance and performance and academic achievement are the ultimate goals of every school or college, it is important that principals know the extent to which their leadership practices potentially influence tutors' performance and student learning. Hence, principals' knowledge of these six factors of transformational leadership and how they influence their tutors' sense of efficacy, could consciously exercise them to enhance tutor performance.

Thirdly, the study also demonstrated that principals' transformational leadership practices such as: providing vision and holding high performance expectations predominantly produced the most effects on tutors' sense of efficacy in student engagement, instructional strategies and classroom management. Whereas the leadership practice of providing vision involves practices such as: 'setting directions and establishing goals, setting directions and establishing goals, identifying new opportunities for the school, developing, articulating and inspiring teachers to share in the vision for the school, principals who actively exercise this leadership practice may enable tutors to see the clear direction they want their colleges to go. In this way, principals who engage in the leadership practice of providing vision may may enable tutors to see the corporate way forward and the commitments that are that are needed for achieving shared college goals.

Having a clearer college vision and sense of direction and sense of direction also sets the standards for best performance. Consequently, this study could help practitioners and stakeholders in education to channel resources towards workshops and professional development programs that focus on transformational leadership practices. Such professional development programs and workshops could be geared toward enabling school leaders and principals to acquire the requisite skills and knowledge on how to clearly define the visions of their schools and colleges. This is because principals with such knowledge will be able to work with their tutors to clearly develop and articulate their college vision in ways that inspire, motivate and galvanise tutors to work towards the achievement of such goals with enthusiasm.

Last but not least, the findings of this study contribute to advancing the literature on educational leadership and the effects of transformational leadership as a multidimension model of leadership in the administration of colleges and schools. Even though the results of this study are to some extent consistent with findings of previous research studies in the area, there is scarcity in research studies which particularly focus on the impact of principals' transformational leadership practices on tutors' sense of efficacy in tertiary institutions. Findings of this current study therefore contribute to the literature in this area.

\section{Limitations of the Study}

The first limitation deals with the sampling used for the study. Denscombe (2014) indicates that 'reliance on findings from a sub-section of the total research population inevitably opens up the prospects that another sample from the same population might produce slightly different findings' (p.52). Even though cluster sampling procedures were carefully followed to select the representative sample of 629 tutors for the study, sampling brings with it some levels of uncertainty when it comes to generalising findings on whole populations.

Secondly, the study also used questionnaires for data collection. This brings with it some potential limitations. While the study used the 24 items of the TSES and the 24 items of the PLQ to garner data on tutors' assessments of their self-efficacy beliefs and perceptions of their principals' leadership practices respectively, such pre-coded questions always bring with them a structure. As Denscombe (2014) put it, questionnaires by their very nature impose a structure 'on responses in a way that reflects the researcher's thinking rather than the respondents' (p.181). Although good and carefully constructed questionnaire may minimise the prospects of this problem, there is always the danger that options open to respondents may represent more of the researcher's perspectives (Denscombe, 
2014).

Last but not least, the study examined tutors' perceptions of their principals' transformational leadership practices using only the six factors of the principal leadership questionnaire (PLQ): that is, providing vision, fostering commitment, modelling best behaviour, providing individual support, intellectual stimulation and holding high performance expectations. Principals of the studied colleges may also exercise other transformational leadership behaviours that are not covered by the PLQ construct. There are other instruments for measuring transformational leadership practices such as the MLQ and NSLS among others. These instruments measure other aspects of transformational leadership that are not constitutive of the PLQ. Consequently, limiting tutors' perceptions of their principals' transformational leadership practices to the six factors of the PLQ may have excluded other leadership practices that are worthy of note and analysis.

\section{Recommendations}

First of all, by using the six factors of the PLQ to measure tutors' perceptions of their principals' transformational leadership practices, it is possible that these principals exercised other forms of leadership behaviours that enhanced their tutors' sense of efficacy. So, a follow-up study that uses qualitative methods such as interviews and focus groups may help uncover other leadership practices in this direction. This could also be done with the use of mixed methods research designs which allow for the triangulation of research findings.

Secondly, a study which further investigates the perceptions of principals on their own leadership practices and self-efficacy beliefs is recommended. It is true that tutors form their perceptions of the leadership practices of their college principals through their experience of leadership. It is also true that these perceptions influence tutors' belief in their capability to organise instructional programmes and achieve intended outcomes. However, since perceptions are subjective in nature, a study that measures the way principals perceive their own leadership practices on the one hand and compares these perceptions with those of their tutors on the other, may offer a deeper and holistic picture on the subject on perceptions of principals' transformational leadership practices.

\section{References}

Akyeampong, K. (2003). Teacher Training in Ghana-Does it Count? (MUSTER Country Report One). Sussex, UK: DFID.

Allix, N. M. (2000).. Transformational Leadership: Democratic or Despotic? Educational Management and Administration, 28(1), 7-20.

Antonakis, J., Avolio, B. J., and Sivasubramaniam, N. (2003). Context and leadership: An Examination of the Nine-Factor Full-Range Leadership Theory Using the Multifactor Leadership Questionnaire. The Leadership Quarterly, 14(3), 261-295.

Artiles, D. (2013). The Rise of American Urbanized Suburban High Schools: Teachers' Perceptions of Leadership. (Ed.D., Fordham University). ProQuest Dissertations and Theses, Retrieved from https://search.proquest.com/docview/1431455832?accountid=12753 (02/03/2018)

Avolio, B. J., Bass, B. M. \& Jung, D. I. (1999).. Re-Examining the Components of Transformational and Transactional Leadership Using the Multifactor Leadership Questionnaire the. Journal of Occupational and Organisational, 72, 441-462.

Avolio, B, J., \& Bass, B. M. (2004). Multifactor leadership questionnaire, manual and sample set (3rd ed.). Menlo Park, CA; Mind Garden Inc.

Avalos, B, J. (2011).. Teacher Professional Development in Teaching and Teacher Education Over Ten Years. Journal of Teaching and Teacher Education, 27, 10-20.

Azodi, D. S. (2006). Principal Leadership, Trust, And Teacher Efficacy. (Ed.D., Sam Houston State University). ProQuest Dissertations and Theses, Retrieved from https://search.proquest.com/docview/304961845?accountid=12753 (02/03/2018).

Bandura, A. (1993).. Perceived Self-Efficacy in Cognitive Development and Functioning. Educational Psychologist, 28(2), 117-148.

......... (1997). Self-Efficacy: The Existence of Control. New York: W. H. Freeman and Company.

Bass, B, M. (1985). Leadership and Performance Beyond Expectations. New York: The Free Press.

.......... (1990). Leader March: A Handbook of Leadership. New York: The Free Press.

(1998). Transformational Leadership: Industrial, Military, and Educational Impact. Mahwah, NJ: Erlbaum.

Bass, B. M. and Avolio, B. J. (1990). The Implications of transactional and Transformational leadership for Individual, team, and Organizational development. Research in Organizational Change and Development, 4, $231-272$.

.. (1993). 'Transformational leadership: A response to cri ques', in Chemers, M, M. \& Ayman, R. (eds.), Leadership Theory and Research: Perspectives and Directions: Academic Press, New York. 49-80.

........ (Eds.). (1994). Improving Organizational Effectiveness Through Transformational Leadership. Thousand 
Oaks, CA: Sage Publications.

. (1999). Two Decades of Research and Development in Transformational Leadership. European Journal of Work and Organizational Psychology, 8(1), 9-32.

Bass, B, M., Avolio, B.J., Jung, D.I., \& Bergson, Y. (2003). Predicting Unit Performance by Assessing Transformational and Transactional Leadership. Journal of Applied Psychology, 88(2), 207-218.

Bell, L. and Bolam, R. (2010). Chapter 6: Teacher professionalism and continuing professional development: contested concepts and their implication for school leaders. In: Bush, T., Bell, L. \& Bolam, R., ed., The Principles of Educational Leadership and Management. London: SAGE, 89-111.

Bell, J. and Woolner, P. (2012). Chapter 18: Development and using questionnaires. in: Briggs, R, A., Coleman, M. \& Morrison, M., ed., Research Methods in Educational Leadership and Management,266-280.

Bennardo, D, P. (2007). The Transformational Leadership Characteristics of The Building Principal as A Predictor of High School Teacher Efficacy. (Ed.D., St. John's University (New York), School of Education and Human Services). ProQuest Dissertations and Theses, Retrieved from https://search.proquest.com/docview/1896629610?accountid=12753

Boadu, K., \& Acquah, B. Y. S. (2013). Training Needs Assessments of Colleges of Education Tutors in Central Region, Ghana. International Journal of Humanities and Social Science, 3(10), 247-254.

Borko, H. (2004). Professional Development and Teacher Learning: Mapping the Terrain. Educational Research, 33(8), 3-15.

Bredeson, P. V. and Johansson, O. (2000). The School Principal's Role in Teacher Professional Development. Journal of In-Service Education, 26(2), 385-401.

Briggs, A. R. J., Coleman, M. \& Morrison, M. (2012). Research Methods in Educational Leadership and Management. SAGE: London: Delhi: Washington DC.

Caprara, G, V., Barbaranelli, C., Stecca, P. and Malone, P, S. (2006) Teacher's Self-Efficacy Beliefs as Determinants of Job Satisfaction and Student Academic Achievement: A Study at the School Level. Journal of School Psychology, 44, 473-490.

Card, N, A. (2012). Applied Met-Analysis for Social Science. New York: The Guilford Press.

Chen, P, P. (2003). Exploring the Accuracy and Predictability of the Self-Efficacy Beliefs of Seventh-grade Mathematics Students. Journal of Learning and Individual Difference, 14, 79-92.

Chen, P, P. and Zimmerman, B. (2007). A Cross-National Comparison Study on the Accuracy of Self-Efficacy Beliefs of Middle-School Mathematics Students. The Journal of Experimental Education, 75(3), 221-244.

Cohen, L., Manion, L., \& Morrison, K. (2016). Research Methods in Education. New Delhi: Routledge.

Colton, C. C. (2016). Exploration of Transformational Leadership and Teacher Self-Efficacy in Integrated Arts Schools. (Ed.D., Grand Canyon University). ProQuest Dissertations and Theses, Retrieved from https://search.proquest.com/docview/1800533823?accountid=12753 (02/03/2018).

Cooper, H. and Hedges, L. V. (eds.), (1994). The Handbook of Research Synthesis. New York: Russell SAGE Foundation.

Cooper, H. M., Hedges, L. V., \& Valentine, J. C. (eds.), (2008). The Handbook of Research Synthesis and MetaAnalysis (2nd Ed.). New York: Russell Sage Foundation.

Clune, M. S. (2013). Transformational Leadership, Teacher Self-Efficacy and Effective use of Instructional Technology Within Online Communities of Practice. (Ph.D., Eastern University). ProQuest Dissertations and Theses, Retrieved from https://search.proquest.com/docview/1787842734?accountid=12753 (02/03/2018)

Critical Appraisal Skills Programme (2006). CASP (Public Health Resource Unit, England) Checklist. [Online] Available at: http://www.cfkr.dk/images/file/CASP\%20instrumentet.pdf (19/04/2018)

Critical Appraisal Skills Programme (2018). CASP (Qualitative Review) Checklist. [online] Available at:https://casp-uk.net/wp-content/uploads/2018/03/CASP-Qualitative-Checklist-Download.pdf (19/04/2018).

Crooks, T, J., Kane, M, T. \& Cohen, A, S. (1996) Threats to the Valid Use of Assessments. Assessment in Education: Principles, Policy \& Practice 3(3), 265-286

Dale, J. C., Jr. (2012). The Correlation of The Perceived Leadership Style of Middle School Principals to Teacher Job Satisfaction and Efficacy. (Ed.D., Liberty University). ProQuest Dissertations and Theses, Retrieved from https://search.proquest.com/docview/1238003178?accountid=12753 (02/03/2018).

Dankwa, J. A. (2013). Transformational Leadership in Colleges of Education in Ghana: Teachers' Perspectives. Journal of Education and Practice, 4(16), 187-195.

Day, C., Gu, Q. and Sammons, P. (2016). The Impact of Leadership on Student Outcomes: How Successful Leaders Use Transformational and Instructional Strategies to Make a Difference. Educational Administration Quarterly, 52(2), 221-258.

Demir, K. (2008). Transformational Leadership and Collective Efficacy: The Moderating Roles of Collaborative Culture and Teachers' Self-Efficacy. Eurasian Journal of Educational Research, 33, 93-112.

Demirdag, S. (2015). Assessing Teacher Self-Efficacy and Job Satisfaction: Middle School Teachers. Journal of 
Educational and Instructional Studies, 3(5), 35-43.

Denscombe, M. (2014). The Research Guide for Small Scale School Research Projects.

Berkshire: England: Open University press.

Elliott, S. E. (2000). The Relationship Between Teacher Efficacy and Principal Leadership Behaviours and Teacher Background Variables in Elementary Schools. (Ph.D., University of Connecticut). ProQuest Dissertations and Theses, Retrieved https://search.proquest.com/docview/304595453?accountid=12753 (02/03/2018).

Elliot, A., \& Woodward, W. (2007). Statistical analysis quick reference guidebook with SPPSS examples (1st ed.). London: Sage Publication .

Espinoza, S. (2013). The Effects of Principal's Transformational Leadership Behaviours On Teacher Leadership Development and Teacher Self-Efficacy. (Doctoral Dissertation, University of Texas Pan-American, 2013. UMI No. 3565648).

Field, A. (2009). Discovering Statistics using SPSS (3rd ed.). London: Sage publication.

Field, A. P. \& Gillett, R. (2010). How to do Meta-Analysis. British Journal of Mathematical and Statistical Psychology, 63 (3), 665-694.

Fitzgerald, T. T. (2015). A Study Exploring Transformational Leadership and its Impact on Teacher Efficacy, Teacher Trust, And Change Readiness. (Ed.D., Concordia University Chicago). ProQuest Dissertations and Theses, Retrieved from https://search.proquest.com/docview/1705816534?accountid=12753 (02/03/2018).

Flad, B. H. (1989). Relationships Between Teacher Perceptions of Principal Support and Teacher Allocation of Time. Dissertations and Theses. Paper 1340. (23/01/2019).

Garet, M, S., Porter, A. C., DeSimone, L., Birman, B, F. and Suk. Y. K. (2001). What Makes Professional Development Effective? Results from a National Sample of teachers. American Educational Research Journal, 38(4), 915-945.

Gavora, P. (2010). Slovak Pre-service Teacher Self-Efficacy: Theoretical and research Considerations. The New Educational Review, 21(2), 17-30.

Ghasemi, A. \& Zahediasl, S. (2012). Normality Test for Statistical Analysis: A Guide for Non-Statisticians. International Journal of Endocrinology Metabolism, 10(2), 486-489.

Gkolia, A., Koustelios, A. and Belias, D. (2018). Exploring the Association Between Transformational Leadership and Teacher's Self-Efficacy in Greek Education System: A Multilevel SEM Model. International Journal of leadership in Education, 21(2), 179-196.

Goddard, R. (2002). A Theoretical and Empirical Analysis of the Measurements of Collective Efficacy: The Development of a Short Form. Educational and Psychological Measurement, 62(1), 97-110.

Goddard, R. D. and Goddard, Y. L. (2001). A Multilevel Analysis of the Relationship between Teacher and Collective Efficacy in Urban Schools. Teaching and Teacher Education, 17, 807-818.

Goddard, R. D., Hoy, W, K. and Hoy, A. W. (2004). Collective Efficacy Beliefs: Theoretical Developments, Empirical Evidence, and Future Direction. Educational Research, 33(3), 3-13.

Hair, J., Anderson, R., Tatham, R., \& Black, W. (1998). Multivariate Data Analysis: with readings. New Jersey: Prentice-Hall.

Hair, J., Black, B., Babin, B., Anderson, R., \& Tatham, R. (2010). Multivariate Data Analysis. London: London Prentice Hall.

Hallinger, P. (2003). Leading Educational Change: Reflections on the Practice of Instructional and Transformational Leadership. Cambridge Journal of Education, 33(3), 329-351.

Hallinger, P. and Heck, R. H. (2010). Leadership for Learning: Does Collaborative Leadership Make a Difference in School Improvement? Educational Management Administration and Leadership, 38(6), 654-678.

Hardman, B. K. (2011). Teacher's Perception of their Principal's Leadership Style and the Effects on Student Achievement in Improving and non-improving schools. Graduate Theses and Dissertations. http://scholarcommons.usf.edu/etd/3726 (23/01/2019).

Hayton, J. C., Allen, D. G. \& Scarpello, V. (2004). Factor Retention Decisions in Exploratory Factor Analysis. Organisational Research Methods, 7(2), 191-205.

Hauserman, C, P. and Stick, S. (2013). The Leadership Teachers Want from Principals: Transformational. Canadian Journal of Education, 36(3), 184-203.

Helms, P. M. (2012). Effective Leadership: Perceptions of Principals and the Teachers they Lead. Education Dissertations and Projects.https://digitalcommons.gardner-webb.edu/education_etd/56 (02/03/2018).

Hoxha, L. and Hyseni-Duraku, Z. (2017). The Relationship Between Educational Leadership and Teachers' selfefficacy. The European Journal of Social and Behavioural Science, 20, 2301-2218.

Hoy, W, K., \& Woolfolk, A. E. (1993). Teachers' Sense of Efficacy and the Organisational Health of the School. The Elementary School Journal, 93, 356-372.

Huberman, M. (1989). The Professional Life Cycle of Teachers. Teachers College Record, 91, 31-57.

Jantzi, D. and Leithwood, K. (1996). Towards an Explanation of the Variations in Teachers' Perceptions of 
Transformational School Leadership. Educational Administration Quarterly, 32(4), 512-538.

Klassen, R. M., \& Chiu, M. M. (2010). Effects on Teachers' Self-Efficacy and Job Satisfaction: Teacher Gender, Years of Experience, and Job Stress. Journal of Educational Psychology, 102(3), 741-756.

Klassen, R. M., Tze, V. M. C., Betts, S. M. and Gordon, K. A. (2011). Teacher Efficacy Research 1998-2009: Signs of Progress or Unfulfilled Promised? Educational Psychology Review, 24, 21-43.

Kor, R. (2010). Teachers' and Principals' Perceptions of Leadership Characteristics and the Relationship of these Perceptions to School Climate. Education Dissertations. http://repository.wcsu.edu/educationdis/76 $(23 / 01 / 2019)$.

Korb, K. A. (2010). Conducting Educational Research: Adopting or Adapting an Instrument.http://korbedpsych.com/R09aAdopt.html (16/10/2019)

Lee, V. E., Smith, J. B., and Cioci, M. (1993). Teachers and Principals: Gender-Related Perceptions and Power in Secondary Schools. Educational Evaluation and Policy Analysis, 15(2), 153-180.

Le Fevre, D, M. and Robinson, V, M. (2015). The Interpersonal Challenges of Instructional Leadership: Principal Effectiveness in Conversations About Performance Issues. Educational Administration Quarterly, 51(1), 5891.

Leithwood, K. (1992). The Move Toward Transformational Leadership. Educational Leadership, 49(5), 8-12.

Leithwood, K. (1994). Leadership for school restructuring. Educational Administration Quarterly, 30(4), 498-518.

Leithwood, K. and Beatty, B. (2008). Leading with Teacher Emotions in Mind. United States of America: Corwin Press: A Sage Company.

....... (2000). The Effects of Transformational Leadership on Organizational Conditions and Student Engagement. Journal of Educational Administration, 38(2), 112- 129.

.... (2005). A Review of Transformation School Leadership Research 1996- 2005. Leadership and Policy in Schools, 4, 177-199.

........ (2006). Transformational School Leadership for Large-Scale Reforms: Effects on Students, Teachers and their Classroom Practices. School Effectiveness and School Improvements, 17(2), 201-227.

Leithwood, K., Jantzi, D. \& Steinbach, R. (1999). Changing Leadership for Changing times. Buckingham, Philadelphia: Open University Press.

Leithwood, K., Day, C., Sammons, P., Harris, A. and Hopkins, D. (2006). Seven Strong Claims about Successful School Leaders. London: DfES

Leithwood, K., Anderson, E. S., Mascall, B. \& Strauss, T. (2010). Chapter 2: School leaders' influence on student Learning: the Four paths. In: Bush, T., Bell, L. \& Bolam, R., ed., The Principles of Educational Leadership and Management. 13-30.

Leithwood, K. and Sun, J. (2012). The Nature and Effects of Transformational Leadership: A Meta-Analytic Review of Unpublished Research. Educational Administration Quarterly, 48(3), 387-423.

Lewandowski, K. . L. (2005). A Study of The Relationship of Teachers' Self-Efficacy and The Impact of Leadership and Professional Development. (D.Ed., Indiana University of Pennsylvania). ProQuest Dissertations and Theses, Retrieved from https://search.proquest.com/docview/305409690?accountid=12753 (02/03/2018).

Ling, T, P., Pihie, Z, A, L., Asimirin, S. and Fooi, F, S. (2015). The Influence of Transformational Leadership on Teacher Efficacy in Malaysian Secondary School Teachers. International Journal of School Science Research, 3(2), 73-85.

Maguire, S. J. (2016). Comparing Transformational and Transactional Leadership Styles of Principals and their Impact on School Climate, Teacher Efficacy and Student Academic Achievement. (Ph.D., Trident University International). ProQuest Dissertations and Theses, Retrieved from https://search.proquest.com/docview/1824687058?accountid=12753 (02/03/2018).

Marks, H. M. and Printy, S. M. (2003). Principal Leadership and School Performance: An Integration of Transformational and Instructional leadership. Educational Administration Quarterly, 39(3), 370-397.

Mascall, M. B. (2003). Leaders Helping Teachers Helping Students: The Role of Transformational Leaders in Building Teacher Efficacy. (Ph.D., University of Toronto (Canada)). ProQuest Dissertations and Theses, Retrieved from https://search.proquest.com/docview/305258796?accountid=12753 (02/03/2018).

McCormick, M. J. (2001). Self-Efficacy and Leadership Effectiveness: Applying Social Cognitive Theory to Leadership. The Journal of Leadership Studies, 8(1), 22-33.

McWilliam, H. O. A., and Kwamena-Poh, M. A. (1978). The Development of Education in Ghana: An Online Third Edition. London: Longman Group Ltd.

Mehdinezhad, V. and Mansouri, M. (2016). School Principals Leadership Behaviours and its Relation with Teachers' Sense of Efficacy. International Journal of Instruction, 9(2), 51-60.

Nelson, A. (2012). The Relationship Between Middle School Teachers' Perceptions of Principals' Transformational Leadership Practices, Teachers' Sense of Efficacy and Student Achievement. (Doctoral Dissertation, University of Southern Mississippi, 2012. UMI No. 3530736). 
Newman, E. (2014). The Upgrading of Teacher Training Institutions to Colleges of Education: Issues and Prospects. African Journal of Teacher Education, 3(2), 2-14.

Nir, A. E., \& Kranot, N. (2006). School Principal's Leadership Style and Teachers' Self-Efficacy. Planning and Changing, 37(3/4), 205-218. $\quad$ Retrieved from https://search.proquest.com/docview/218774333?accountid=12753 (02/03/2018).

Odoom, D., Opoku, E., \& Ayipah, D. N. (2016). Staff Development Needs at the Colleges of Education in Ghana: Evidence from Agogo College. International Journal of Innovative Research \& Development, 1, 127-137.

Ontai-Machado, D. (2016). Teachers' Perceptions of Elementary School Principals' Leadership Attributes and Their Relationship to School Effectiveness. Walden University https://scholarworks.waldenu.edu/dissertations (23/01/2019).

Osei, A. A., \& Adu, K. O. (2016). Transitional Challenges Facing Staff Development in Selected Colleges of Education in Ghana. International Journal of Research in Education and Social Science, 4, 301-315.

Pajares, F. (1997). Current Directions in Self-Efficacy Research: in Maehr, M. \& Pintrich, P, R., (Eds.) Advances in motivation and achievement. Bingley: UK: Emerald Group Publishing Ltd.

Pallant, J. (2007). SPSS survival manual, a step by step guide to data analysis using SPSS for wisdows (3 ed.). Sydney: McGraw Hill.

Pegler, P. L. (2003). An Examination of Teacher Efficacy and Transformational Leadership Behaviours of Principals in Urban Middle Schools. (Ph.D., Howard University). ProQuest Dissertations and Theses, Retrieved from https://search.proquest.com/docview/305330150?accountid=12753(02/03/2018).

Randolph, J. (2009). A Guide to Writing the Dissertation Literature Review. Practical Assessment, Research \& Evaluation, 14(13), 1-13.

Rhodes, C. and Brundrett, M. (2010). Chapter 9: Leadership for learning. In: Bush, T., Bell, L. \& Bolam, R., ed., The Principles of Educational Leadership and Management. 153-175.

Riggs, R. (2017). Correlational Study Between Teacher Perceived High School Principal Leadership Style and Teacher Self-Efficacy. (Ed.D., Grand Canyon University). ProQuest Dissertations and Theses, Retrieved from https://search.proquest.com/docview/1952261914?accountid=12753 (02/03/2018).

Ross, J. and Gray, P. (2006). Transformational leadership and Teacher Commitment to Organisational Values: The Mediating Effects of Collective Teacher Efficacy. School Effectiveness and School Improvement, 2, 179199

Ross, J and Bruce, C. (2007). Professional Development Effects on Teacher Efficacy: Results of Randomised Field Trial. The Journal of Educations Research, 101(1), 50-60.

Rowold, J. (2005). Multifactor Leadership Questionnaire: Psychometric Properties of the German Translation. Mind Garden Inc.

Ryan, H. D. (2007). An Examination of The Relationship Between Teacher Efficacy and Teachers' Perceptions of Their Principals' Leadership Behaviours. (Ed.D., University of North Texas). ProQuest Dissertations and Theses, Retrieved From https://search.proquest.com/docview/304821039?accountid=12753 (02/03/2018).

Shatzer, R, H., Caldarella, P., Hallam, P. and Brown, B, L. (2013). Comparing the Effects of Instructional and Transformational Leadership on Student Achievement: Implications for Practice. Educational Management Administration and Leadership, 42(4), 445-459.

Short, J. J. (2016). Teachers' Self-Efficacy and Their Perceptions of Principals' Transformational Leadership Practices. (Ed.D., Baker University). ProQuest Dissertation and Theses.

Shumate, R. L. (2011). Transformational Versus Transactional Leadership: Which Perceived Leadership Style Has the Stronger Relationship Between Teacher Efficacy and Student Achievement? (Ed.D., Trevecca Nazarene University). ProQuest Dissertations and Theses, Retrieved from https://search.proquest.com/docview/877976459?accountid=12753 (02/03/2018).

Transforming Teacher Education and Learning (T-TEL) in Ghana (2015): Ministry of Education (Ghana). Creative Commons Attribution-Share-Alike 4.0 International License. www.t-tel.org. (14/11/18).

Transforming Teacher Education and Learning (T-TEL). (2016). Unit 3: Leading Institutional Strengthening (Operations Leadership) - Leadership Programme Resources for College Leaders. Ghana: Ministry of Education.

Tschannen-Moran, M., Hoy, A, W., Woolfolk H. A., \& Hoy, W, K. (1998). Teacher Efficacy: Its Meaning and Measure. Review of Educational Research, 68(2), 202-248.

Tschannen-Moran, M. and Woolfolk Hoy, A. (2001). Teacher Efficacy: Capturing an Elusive Construct. Teaching and Teacher Education, 17(7), 783-805.

Tschannen-Moran, M. and Woolfolk Hoy, A. (2007). The Differential Antecedents of Self-Efficacy Beliefs of Novice and Experienced Teachers. International Journal of Teaching and Teacher Education, 23, 944-956.

Tschannen-Moan, M. and McMaster, P. (2009). Sources of Self-Efficacy: Four Professional Development Formats and Their Relationship to Self-Efficacy and implementation of a New Teaching Strategy. The Elementary School Journal, 110(2), 228-245. 
Tschannen-Moran, M. and Slear, C. (2004). Principal Sense of efficacy: Assessing a Promising Construct. Journal of Educational Administration, 42(5), 573-585.

Urick, A. and Bowers, A. (2014). What are the Different Types of Principals Across the United States? A Latent Class Analysis of Principal Perceptions of Leadership. Educational Administration Quarterly, 50(1), 96-134.

Vaudroz, C., Berger, J., \& Girardet, C. (2015). The Role of Teaching Experience and Prior Education in Teachers' Self-Efficacy and General Pedagogical Knowledge at the Onset of Teacher Education. International Journal of Teaching and Educational Research, 13(2), 168-178.

Versland, T, M. and Erickson, J. (2017). Leading by Example: A Case Study of the influence of Principal SelfEfficacy on Collective Efficacy. Cogent Education 4, 1-17.

Walker, J. and Slear, S. (2011). The Impact of Principal Leadership Behaviour on the Efficacy of New and Experienced School Teachers. NASSP Bulletin, 95(1), 46-64.

Ware, H. and Kitsantas, A. (2007). Teacher and Collective Efficacy Beliefs as Predictors of Professional Commitment. Journal of Educational Research, 100(5), 303-310.

Wayne, A, J., Suk Y. K., Zhu, P., Cronen, S. and Garet, M. (2008). Experimenting with Teacher Professional Development: Motives and Methods. Educational research, 37(8), 469-479.

Williams, E. Jr., (2006). "Teachers' Perceptions of Principal Leadership in Relation to Student Achievement. ETD Collection for AUC Robert W. Woodruff Library Paper AAI3258821. (23/01/2019).

Williams, D. P. (2010). Outcome Expectancy and Self-Efficacy: Theoretical Implications of an Unresolved Contradiction. Personality and Social Psychology Review, 14(4), 417-425.

Wilson, M. (2014). Critical Reflection on Authentic Leadership and School Leader Development from a Virtue Ethical Perspective. Educational Review. 66(4), 482-496.

Wolters, C. A., \& Daugherty, S. G. (2007). Goal Structures and Teachers' Sense of Efficacy: Their Relation and Association to Teaching Experience and Academic Level. Journal of Educational Psychology, 99, 181-193.

Woolfolk Hoy, A. \& Burke Spero, R. (2005). Changes in Teacher Efficacy During the Early Years of Teaching: A Comparison of Four Measures. Teaching and Teacher Education, 21, 343-356.

Yukl, G. A. (1999). An Evaluation of Conceptual Weaknesses in Transformational and Charismatic Leadership Theories. Leadership Quarterly, 10, 285-305. 